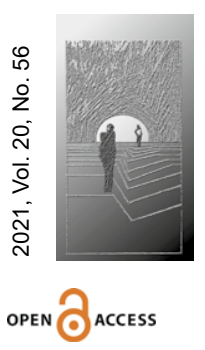

\title{
Neuroróżnorodnodność studentów
} w uczelni wyższej w dyskursie kompensacyjno-terapeutycznym i dyskursie otwierania potencjału. Część I

\section{STRESZCZENIE}

CEL NAUKOWY: Celem moich badań jest próba nadania znaczeń istotnych dla przygotowania się nauczyciela akademickiego do procesu dydaktycznego sprzyjającego otwieraniu potencjalnych możliwości studentów z autyzmem oraz zespołem Aspergera.

PROBLEM I METODY BADAWCZE: Problemami badawczymi były pytania: Jak przygotować się do procesu dydaktycznego, aby stworzyć studentom w spektrum autyzmu i z zespołem Aspergera możliwości rozwinięcia własnego potencjału? Czy studenci neuroróżnorodni potrzebują specjalnego wsparcia kompensacyjno-terapeutycznego ze strony nauczyciela akademickiego? Hermeneutyczne rozważania osadzone zostały w logice paradygmatu konstruktywistycznego odnoszącego się do dydaktycznych i społecznych wymiarów tworzenia rzeczywistości edukacyjnej. Materiał badawczy stanowią opublikowane teksty źródłowe z przeprowadzonych eksploracji, dotyczące różnych wymiarów obecności w uczelni wyższej studentów ze spektrum autyzmu i z zespołem Aspergera.

PROCES WYWODU: Artykuł otwiera zdefiniowanie kategorii dotyczących autyzmu oraz opisanie dynamiki wzrostu liczby studiujących z tą diagnozą. Następnie opisano w świetle zgromadzonych badań dyskurs kompensacyjno-terapeutyczny i jego znaczenie dla przekonań nauczycielskich. Ostatnia część jest nadawaniem znaczeń procesowi dydaktycznemu, którego sensem jest otwieranie potencjału studentów.

WYNIKI ANALIZY NAUKOWEJ: Przygotowanie do procesu dydaktycznego nauczyciela akademickiego obejmuje konieczność poznania fenomenu autyzmu, co ma znaczenie dla wytworzenia przekonań o możliwościach i potrzebach studentów z tą diagnozą. Studenci neuroróżnorodni w normie intelektualnej i powyżej nie potrzebują od nauczyciela akademickiego wsparcia kompensacyjno-terapeutycznego. Wsparcie tego typu otrzymuje student i nauczyciel od uczelnianych specjalistów do spraw osób niepełnosprawnych. Specyfika poznawcza neuroróżnorodnych studentów predysponuje ich do kształcenia akademickiego, choć mogą się pojawić pewne zaburzenia sytuacyjne lub chorobowe. Studiowanie może być dla nich szansą na wzmocnienie poczucia wartości i przygotowania się do życia dorosłego. Wysoka świadomość siebie, sposobów uczenia się oraz własnych potrzeb czyni ich partnerem w procesie dydaktycznym.

Sugerowane cytowanie: Cierzniewska, R. (2021). Neuroróżnorodnodność studentów w uczelni wyższej w dyskursie kompensacyjno-terapeutycznym i dyskursie otwierania potencjału. Część I. Horyzonty Wychowania, 20(56), 119-132. DOI: 10.35765/hw.2154. 


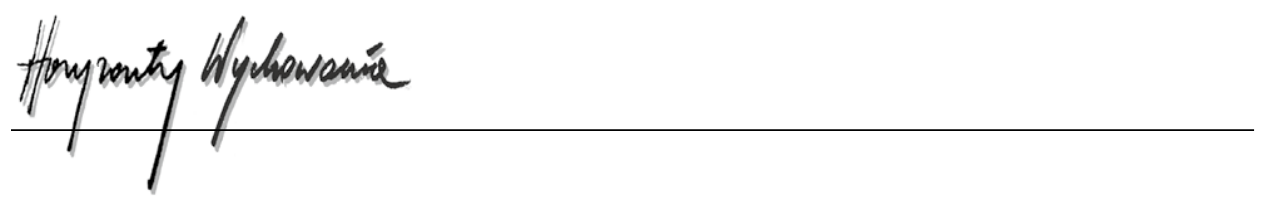

WNIOSKI, INNOWACJE, REKOMENDACJE: W Polsce jest niewiele badań dotyczących studentów neuronietypowych. Dominuje medyczne podejście do autyzmu, natomiast brakuje pedagogicznych opracowań wzmacniających nauczycieli akademickich.

$\begin{array}{ll}\rightarrow \text { SŁOWA KLUCZE: } & \text { EDUKACJA W UCZELNI WYŻSZEJ, STUDENCI ZE SPEKTRUM } \\ & \text { AUTYZMU I Z ZESPOŁEM ASPERGERA, PRZEKONANIA } \\ & \text { NAUCZYCIELSKIE, WSPOMAGANIE STUDENTÓW }\end{array}$

\begin{abstract}
Neurodiversity of Higher Education Students in the Compensatory and Therapeutic Discourse and the Discourse of Unlocking Their Potential. Part I

RESEARCH OBJECTIVE: The aim of my research is an attempt to give meanings that are crucial for the preparation of an academic teacher to the didactic process which is conducive to unlocking potential of students with autism and Asperger's Syndrome.
\end{abstract}

PROBLEM AND RESEARCH METHODS: The research problems were defined in the following questions: How to prepare self for the didactic process to create opportunities for students with the autism spectrum disorder and Asperger's Syndrome to develop their own potential? Do neurodiverse students need special compensatory and therapeutic support from an academic teacher? Hermeneutic approach is embedded in the constructivist paradigm relating to the didactic and social dimensions of creating an educational reality. The research material consists of published sources from the conducted research explorations, concerning various dimensions of the presence of students with the autism spectrum and Asperger's syndrome at universities.

THE PROCESS OF ARGUMENTATION: The article opens with the definition of categories related to autism and the description of the dynamics of the increase in the number of students with this diagnosis. Then, in the light of the collected research, the compensatory-therapeutic discourse and its importance for teachers' beliefs were described. The last part is about giving meaning to the didactic process, the meaning of which is to unlock the students' potential.

RESEARCH RESULTS: Preparation for the didactic process of an academic teacher includes the need to learn about the phenomenon of autism, which is important for forming beliefs about the possibilities and needs of students with this diagnosis. Neurodiversity students within the intellectual norm and above do not need compensatory and therapeutic support from an academic teacher. This type of support is provided to students and teachers from university specialists for people with disabilities. The cognitive specificity of neurodifferent students predisposes them to academic education, although certain situational or disease disorders may occur. Studying can be an opportunity for them to strengthen their self-esteem and prepare for adult life. High selfawareness, awareness of the ways of studying and their own needs makes them a partners in the didactic process. 
CONCLUSIONS, INNOVATIONS AND RECOMMENDATIONS: In Poland, a narrow scope of research on neurodiverse students is observed. The medical approach to autism dominates, while there is the lack of pedagogical studies that strengthen academic teachers.

$\rightarrow$ KEYWORDS: UNIVERSITY EDUCATION, HIGHER EDUCATION, STUDENTS WITH THE AUTISM SPECTRUM AND ASPERGER'S SYNDROME, TEACHER BELIEFS, SUPPORTING STUDENTS

\section{Wprowadzenie}

Edukacją dzieci i młodzieży z zespołem Aspergera oraz z autyzmem badacze z różnych dyscyplin zajmują się stosunkowo intensywnie, jednak w obszarze edukacji akademickiej jest wyraźny niedosyt eksploracji dotyczących pracy dydaktycznej ze studentami charakteryzującymi się neuroróżnorodnością. Również niewiele jest badań odnoszących się do relacji pomiędzy podmiotami edukacji w uczelni wyższej. Dominują badania medykalizujące dyskurs o autyzmie, podnoszące kwestię spektrum autyzmu i zespół Aspergera w kategoriach choroby, zaburzeń i wynikających z nich trudności oraz barier edukacyjnych. Z przeanalizowanych badań mocno wybrzmiewa zalecenie wspierania studentów w różnych wymiarach w ramach działań kompensacyjno-terapeutycznych oraz opisuje się coraz bardziej rozbudowany system wspomagania uruchamiany w poszczególnych uczelniach wyższych. Zidentyfikowany deficyt w obrębie pedagogiki szkoły wyższej oraz pedagogiki specjalnej prowokuje do podjęcia badań. $Z$ tej perspektywy wyłonił się cel moich badań, którym była próba nadania znaczeń procesowi przygotowania się nauczyciela akademickiego do realizacji procesu dydaktycznego sprzyjającego otwieraniu potencjalnych możliwości studentów z autyzmem oraz zespołem Aspergera. Postawiłam następujące pytania badawcze: Jak przygotować się do procesu dydaktycznego, aby stworzyć studentom w spektrum autyzmu możliwości rozwinięcia własnego potencjału? Czy studenci neuroróżnorodni potrzebują specjalnego wsparcia kompensacyjno-terapeutycznego ze strony nauczyciela akademickiego? Hermeneutyczne rozważaniach osadzone są w logice paradygmatu konstruktywistycznego odnoszącego się do dydaktycznych (zob.: Klus-Stańska, 2018; Sajdak, 2013) i społecznych aspektów konstruowania rzeczywistości edukacyjnej (Schütz, 2008; Berger i Luckman, 2010). Materiał badawczy stanowią teksty źródłowe z przeprowadzonych eksploracji, dotyczące różnych wymiarów obecności w uczelni wyższej studentów ze spektrum autyzmu i zespołem Aspergera. Nadmieniam, że wyniki prowadzonych przeze mnie badań zostały opisane w dwóch odrębnych artykułach, z czego pierwszy dotyczy nadawania nauczycielskich znaczeń pracy dydaktycznej ze studentem neuroróżnorodnym, natomiast w drugim został ujęty opis specyfiki funkcjonowania i procesów poznawczych osób ze spektrum autyzmu wraz ze wskazaniem możliwości wydobywania potencjału młodych ludzi. Dodam, że od niemalże dwóch lat prowadzę również w tym zakresie badania. 


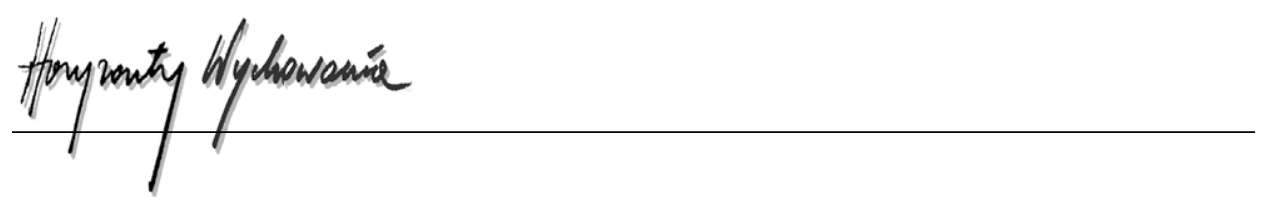

\section{Neuroróżnorodność studentów}

W uczelni wyższej podejmą studia osoby z zespołem Aspergera (ZA) oraz z autyzmem wysokofunkcjonującym, a więc z lżejszymi wersjami autyzmu. Poziom trudności funkcjonowania z tymi diagnozami jest znacznie łagodniejszy i dotyczy od 50 do $70 \%$ populacji osób w spektrum autyzmu. Podstawowym wskaźnikiem dla obydwóch diagnoz jest iloraz inteligencji w normie intelektualnej lub powyżej. Autyzm jest fenomenem wysoce zróżnicowanym w zakresie rodzaju obserwowalnych zachowań, natężenia oraz ich zmienności rozwojowej i sytuacyjnej, co wpływa nie tylko na trudności w postawieniu diagnozy, ale również kreowanie korzystnych warunków procesu dydaktycznego. Uta Frith, twórczyni kategorii spektrum autyzmu, zamiast statycznej diagnozy zasugerowała zastosowanie dynamicznej, śledzącej indywidualną trajektorię rozwojową, przeprowadzonej na podstawie jakościowej obserwacji i interpretacji zachodzących zmian. Kliniczne doświadczenia Frith i innych badaczy potwierdziły słuszność wczesnej interwencji terapeutycznej oraz stymulujące znaczenie kontekstu społeczno-edukacyjnego dla występowania progresu rozwojowego (Frith, 2005; Grandin i Panek, 2021; Simone, 2016; Prizant i Fields-Meyer, 2017). Klinicyści wyodrębnili trzy sfery, w ramach których występują inne niż u osób neuronormatywnych zachowania: sfera socjalizacji (zachowania społeczne), komunikacji (wzajemne interakcje i komunikacja werbalna i/lub niewerbalna) oraz schematycznego myślenia i poznania (ograniczone i/lub powtarzalne stereotypowe wzorce czynności i zainteresowań). Warunkiem postawienia diagnozy o autyzmie jest występowanie symptomów w każdej z wymienionych sfer (Pisula, 2018, s. 10-11). W rozszerzonej wersji ujmuje się również problemy w sferze wykonawczej (planowanie, organizowanie, obserwowanie progresu w drodze do celu, problemy z elastycznym modyfikowaniem strategii działania) oraz nietolerancję sensoryczną (Huang i Wheeler, 2006; Dijkhuis i in., 2020; Bogdashina, 2019). Należy dodać, że kryteria autyzmu odpowiadają fenotypowi męskiemu, zaś dziewczęta/kobiety w normie intelektualnej i powyżej, a więc z lżejszymi symptomami autyzmu były przez klinicystów lekceważone i nie uzyskiwały stosownego wsparcia terapeutycznego i edukacyjnego (Rynkiewicz i in., 2012, Sławińska, 2014; Hull i in., 2020; Simone, 2016; Krahn i Fenton, 2012). Z dużym prawdopodobieństwem nauczyły się kamuflować swoje odmienności, wytworzyły trudne i wyczerpujące je mechanizmy dostosowawcze (Hendrickx, 2018; Hull i in., 2020; Kim, 2018; Simone, 2016). Zróżnicowanie pomiędzy ZA i autyzmem występuje w zakresie mowy (czasu opanowania i sprawności w posługiwaniu się nią). W przypadku osób z ZA język jest bardziej ekspresyjny, otwarty, bywa duży zasób słownictwa, pamięć werbalna, elastyczność w zastosowaniu zestawów pojęciowych. W przypadku osób z autyzmem sprawność mówienia osiągana jest później, bywają osoby rozwijające pełną swobodę mówienia, ale również i takie, które znacznie lepiej wyrażają się w piśmie (Frith, 2005).

W tytule artykułu przywołałam kategorię „neuroróżnoroności”, zastępując nią terminy „autyzm” i zespół Aspergera, co jest akcentem „wchodzącej” zmiany paradygmatycznej. Dominujący paradygmat medyczny ujmuje autyzm i inne zaburzenia neurorozwojowe jako objawy zaburzonych stanów i deficytów w różnych sferach, które należy 
objąć leczeniem. Apologeci koncepcji neuroróżnorodności twierdzą, że autyzmu nie można wyleczyć, gdyż to nie jest choroba, a rolą osób wspomagających jest odnajdywanie sposobów, które pozwolą zidentyfikować potencjał tkwiący w jednostce zgodnie z neurologicznymi predyspozycjami. Mówiąc precyzyjniej, w koncepcji neuroróżnorodności spektrum autyzmu i zespół Aspergera wraz z dysleksją i ADHD są postrzegane nie w kategorii deficytu czy dysfunkcji, ale jako naturalne/osobnicze cechy mechanizmów poznawczych (Molloy i Vasil, 2002, s 659-669). Sugeruje się zastąpienie określenia „zaburzenie", które jest potencjalnie stygmatyzujące, pojęciem stanu autyzmu (Rynkiewicz i in., 2019). W rzeczy samej w idei neuroróżnorodności chodzi o zgoła odmienne postrzeganie funkcjonalności mózgu, o wyeliminowanie binarnych kategorii normalności i anormalności oraz dostrzeżenie zróżnicowania w rozwoju każdego z nas. Trudno zaprzeczyć poglądowi, że wszyscy jesteśmy neuroróżnorodni, wszak rodzimy się z różną lateralizacją, z odmienną wrażliwością sensoryczną czy zdolnościami. Uczymy się również inaczej, osobniczo preferując jedną lub więcej aktywności (słuchanie, czytanie, działanie, rozwiązywanie problemów itd.) i wszystko występuje naturalnie, a z odmiennością uczymy się żyć (Baron-Cohen, 2021, s. 210-211).

\section{Dynamika wzrostu liczby studentów neuroróżnorodnych}

Badania nad autyzmem zapoczątkowane przez Leo Kannera oraz Hansa Aspergera, a rozpropagowane i pogłębione przez Utę Frith i Lornę Wing (2005) wraz z innymi badaczami, uruchomiły ogromną liczbę eksploracji, które z jednej strony przyniosły nowe fakty sprawiające lepsze rozumienie autyzmu, jednak z drugiej nie odsłoniły przyczyny jego powstawania. Obecnie zakłada się działanie wielu czynników, w tym genetycznych, hormonalnych, neuronalnych z biochemicznymi, ale również szeroko rozumianych wpływów cywilizacyjnych (Charlton i Rosenkranz, 2016). Faktem niezaprzeczalnym natomiast jest istotny wzrost liczby osób z diagnozą spektrum autyzmu. Uważa się, że jest on spowodowany rozszerzaniem kryteriów opisujących zaburzenie oraz zwiększaniem się świadomości lekarzy, psychologów, pedagogów i rodziców. Sugeruje się nawet, że uruchomiony system wsparcia niesiony rodzinom oraz osobom z autyzmem jest mechanizmem zachęcającym do poddawania się diagnostyce. Należy jednak zaznaczyć, że opieka socjalna, edukacyjna, medyczna, rehabilitacyjna, a wraz z nią przyznawane udogodnienia i świadczenia socjalne (zasiłki, stypendia, klasy integracyjne, stała opieka medyczna, rehabilitacyjna i inne), choć na całym świecie są w bardzo zróżnicowanej ofercie, to jednak wszędzie poziom zadowolenia ze wsparcia jest niski. Obecnie nie ma jednoznacznego rozstrzygnięcia, co przyczynia się do istotnie zwiększającej się liczby osób w spektrum autyzmu, ale można założyć, że każdy z czynników ma pewne znaczenie (Rybakowski i in., 2014).

W latach 80. XX w. zdiagnozowano autyzm u 0,05\% populacji, obecnie ogólnoświatowe zestawienia statystyczne sugerują możliwość występowania autyzmu nawet u $1 \%$ ogółu ludności. Istotnie wyższą liczbę z potwierdzoną diagnozą identyfikują statystyki 


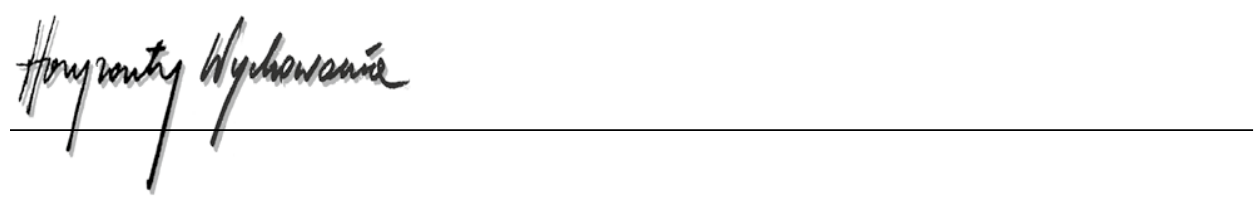

amerykańskie z 2014 r., wskazując, że w USA osób ze spektrum autyzmu i ZA jest 1,47\% populacji. Dane pochodzące z Wielkiej Brytanii osiągnęły wskaźnik 1,1\%. Autorzy raportu NIK podają, że można przyjąć szacunkowo, iż 0,6\% ludności w Unii Europejskiej ma autyzm, a więc w przybliżeniu 5 mln osób (NIK, 2020).

W Polsce tylko na podstawie danych pochodzących z Systemu Informacji Oświatowej (SIO) możemy w przybliżeniu określić liczbę dzieci i młodzieży z diagnozą autyzmu lub zespołem Aspergera, natomiast Elektroniczny Krajowy System Monitoringu Orzekania o Niepełnosprawności pozwala na określenie, ilu osobom po 2010 roku przyznano orzeczenie o niepełnosprawności z rozpoznaniem autyzmu lub zespołu Aspergera. Analiza danych zebranych przez NIK wskazuje, że w kolejnych latach między 2016 i 2019 każdego roku liczba uczniów zwiększała się około 20\%. Z zebranych danych wynika, „że zdiagnozowano autyzm lub zespół Aspergera u jednego ucznia na 115 (0,87\%)" (NIK, 2020). W kolejnych ogólnopolskich badaniach przeprowadzonych na zlecenia Ośrodka Rozwoju Edukacji i Ministerstwa Edukacji i Nauki, opracowanych przez Dorotę Podgórską-Jachnik, mamy potwierdzenie wzrostu liczby dzieci z orzeczeniami o autyzmie i zespole Aspergera. Dane zebrane na przełomie roku 2019 i 2020 roku wskazują, że dzieci z orzeczeniami o autyzmie i zespole Aspergera było w przedszkolach i szkołach łącznie 48 073. Z tego wynika znacznie większy wzrost niż $20 \%$, co sugerowały wcześniejsze badania (Podgórska-Jachnik, 2021).

Kontrola NIK wykazała, że

(...) w latach 2016/2017-2018/2019 większość uczniów z autyzmem lub zespołem Aspergera kontynuowała edukację w liceach ogólnokształcących i technikach. Średnie wyniki egzaminów maturalnych, uzyskiwane w latach 2017-2019 przez absolwentów z autyzmem lub zespołem Aspergera nie różniły się znacznie od (...) innych absolwentów. Nieco niższe wyniki (...) notowano tylko w odniesieniu do egzaminu z matematyki na poziomie podstawowym, jednak w rozszerzeniach z matematyki i języka angielskiego średni wynik był krocząco wyższy (NIK, 2020, s. 42).

W Polsce nie prowadzi się monitoringu studentów z autyzmem i zespołem Aspergera, również Ministerstwo Edukacji i Nauki (MNiSW) nie gromadzi danych statystycznych dotyczących struktury osób z niepełnosprawnościami, w tym studentów z zaburzeniami ze spektrum autyzmu (NIK, 2020, s. 43). Przyjmując statystyczne szacowanie, wśród ogółu osób w spektrum autyzmu około 50\% (Pisula, 2018; Baron-Cohen, 2021) jest w normie intelektualnej lub powyżej, z czego $20 \%$ ma wybitne uzdolnienia (Attwood, 2013, s. 23), a zatem teoretycznie rzecz ujmując, na przestrzeni kilku lat może podjąć kształcenie w szkołach wyższych około 20 tys. studentów z taką diagnozą. Należy również uwzględnić, że część osób otrzymuje rozpoznanie w późniejszym wieku (Hendrickx, 2018; Pisula, 2018; Simone, 2016). Wielu studentów zgłaszających się do biur pełnomocników rektorów do spraw osób niepełnosprawnych nie decyduje się na ujawnienie diagnozy (takie ich prawo) bądź jej nie ma i mimo tego otrzymują pomoc, co gwarantuje im ustawa Prawo o szkolnictwie wyższym i nauce z 2018 roku. Z informacji uzyskanych przez NIK (z dwunastu uczelni wyższych uniwersytetów i politechnik) wynika, że 
na uczelniach tych kształcili się studenci i doktoranci ze spektrum zaburzeń autyzmu, którzy najczęściej informowali o diagnozie Biura ds. Osób Niepełnosprawnych lub prowadzących zajęcia i/albo opiekunów roku.

W roku akademickim 2018/2019 w ankietowanych uczelniach było od dwóch do 33 studentów z zaburzeniami ze spektrum autyzmu. Mimo otrzymanego wsparcia w latach 2016/20172018/2019 w połowie uczelni studenci z tymi zaburzeniami rezygnowali ze studiów lub zmieniali kierunki z powodu trudności w funkcjonowaniu społecznym" (NIK, 2020, s. 44).

Podobne zjawisko obserwowane jest na całym świecie przez wielu badaczy (np. Cai i Richdale, 2016; Cullen, 2015; Moore-Gumora, 2014; Stefańska-Klar, 2010), a najwięcej rezygnacji dotyczy pierwszego roku studiów. Z drugiej strony mamy już potwierdzenia, że studenci neuronienormatywni nie mają kłopotów z akademickimi kompetencjami (Bakker i in., 2019), choć część badaczy twierdzi, że funkcjonalność poznawcza jest połączona ze sferą wykonawczą, której sprawność pozwala przewidzieć wyniki w nauce (Dijkhuis i in., 2020). Jest zatem problem nie tylko ze wzrostem potencjalnej liczby studentów w spektrum autyzmu, ale również ze stworzeniem warunków do studiowania, tak aby ograniczyć rezygnację ze studiów. Badania przeprowadzone w Polsce również potwierdzają ten wniosek (Stefańska-Klar, 2010; NIK, 2020).

\section{Przekonania nauczycielskie pomiędzy dyskursem kompensacyjno- -terapeutycznym a dyskursem otwierania potencjału}

Syntetycznie opisałam spektrum autyzmu i zespołu Aspergera, gdyż dla profesjonalnego działania nauczyciela akademickiego niezbędna jest wiedza o tym, z kim pracuje, oraz świadomość własnych przekonań dotyczących podmiotów edukacji (własnej roli oraz pozycji/miejsca studentów, czyli statusu ontologicznego). Mówię o filozofii leżącej u podstaw własnej pedagogii i znaczenia tych modalności (w sensie ontologicznym) dla podejmowanych decyzji dydaktycznych. Zwracam uwagę, że opowiadam się za zastąpieniem epistemologii interpretacji (np. interpretacji działań pedagogicznych) ontologią rozumienia, gdyż każdy podmiot (nauczyciel, student, grupa studencka) jest nosicielem pewnych intencji, którym nadaje znaczenia. Moja hermeneutyczna deklaracja spełnia dwie funkcje, odnosząc się do kategorii „bycia” nauczycielem akademickim oraz tu opisanych badań. Rozumienie, w tym przypadku istoty procesu dydaktycznego, nie jest aktem poznawczym, lecz - jak powiada Paul Ricoeur - „sposobem bycia tego bytu, który egzystuje przez rozumienie" (1985, s. 186). W takim podejściu mieści się filozofa paradygmatu konstruktywistycznego w odniesieniu do dydaktycznych (zob.: Klus-Stańska, 2018; Sajdak, 2013) i społecznych aspektów konstruowania rzeczywistości edukacyjnej (Schütz, 2008; Berger i Luckman, 2010).

Powrócę do kategorii przekonań, gdyż przebieg procesu edukacyjnego oraz jego efekty w dużej mierze są ich wypadkową (Cisłak i in., 2009). Stanowią naszą mapę mentalną, którą wypełnia system poznawczo-motywacyjno-afektywny regulujący nasze 


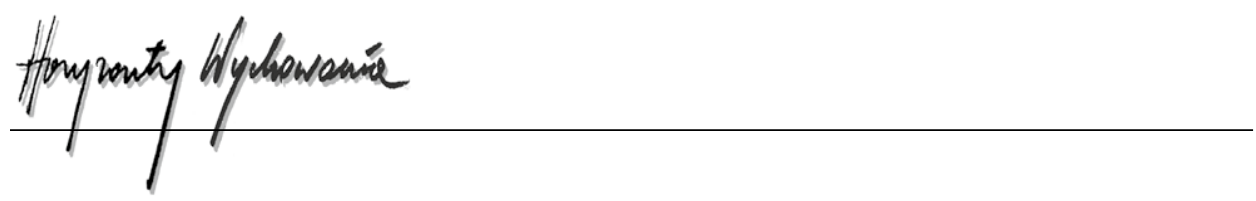

zachowanie. Tu jest „zapisany” stosunek do rzeczywistości, innych ludzi i siebie samego (Brzezińska i in., 2010 s. 12-13). Istotną właściwością naszych przekonań jest ich moc sprawcza na poziomie uświadomionym i nieuświadomionym, czego dowiodły opisane przez badaczy eksperymenty dotyczące zmiany zachowań nauczyciela pod wpływem informacji o potencjale intelektualnym uczniów. Wytworzone przekonania zmieniły ich czynności dydaktyczne oraz zaangażowanie uczniów, wpływając na podniesienie jakości procesu oraz uzyskanie istotnie wyższych efektów kształcenia sprzyjających uruchomieniu potencjału uczących się (Cisłak i in., 2009; Trusz, 2011).

Nauczycielskie nastawienia widoczne są w relacjach między podmiotami edukacji. Okazuje się, że studenci neuroróżnorodni obok dużej życzliwości doświadczyli gotowości do dodatkowych konsultacji online i dostępności na zajęciach, także unikania bezpośredniego kontaktu, lekceważenia zgłaszanych problemów, a nawet o wrogości. W badaniach Opatowicz jeden ze studentów stwierdził, że „nikt we mnie nie wierzył”, co doskonale uwypukla sensy i znaczenia nadawane relacjom z nauczycielem akademickim (Opatowicz, 2021; Cullen, 2015; Gelbar i in. 2014; Cai i Richdale, 2016). Marcin Płatos wraz z zespołem również wskazuje na przewagę pozytywnych ocen studenckich dotyczących relacji z wykładowcami (58\%) i udziału w zajęciach 47\%. Kolejnym ważnym ustaleniem były osiągnięcia edukacyjne, które w opinii $63 \%$ badanych studentów zostały uznane za dobre i bardzo dobre. Najmniej satysfakcjonujące były relacje z rówieśnikami 37\% (Płatos, 2016). W badaniach jakościowych wystąpiły podobne opisy i również zdecydowanie niżej oceniane były relacje z innymi studentami, w których pojawiły się incydenty dyskryminacji, wrogości, odrzucenia, osamotnienia, trudności w nawiązaniu kontaktów, zwłaszcza w trakcie pracy w grupie. Obok tego wystąpiły odpowiedzi opisujące bardzo dobre kontakty zarówno we własnej grupie, jak i za pośrednictwem mediów społecznościowych (Opatowicz, 2021, Cullen, 2015; Gelbar i in. 2014; Cai i Richdale 2016).

W świetle opisanych mechanizmów zaczerpniętych z klasycznej „teorii światów” Alfreda Schütza można stwierdzić, że w przestrzeni akademickiej nie ma uspójnionego nastawienia pozytywnego bądź negatywnego, co - jak sądzę - rokuje sukces w dalszych negocjacjach znaczeń. Nauczyciele akademiccy i studenci stopniowo oswajają się z obecnością jeszcze nielicznych studentów neuroróżnorodnych, nadto sadzę, że występuje brak pogłębionej wiedzy dotyczącej autyzmu, co również sygnalizowali badacze (Stefańska-Klar, 2010; Gurbuz i in., 2019; Banach i Krzanowska, 2017). Natomiast czynnikiem wywołującym opór nauczycieli akademickich może być niejasność nowych zadań wynikających z obecności w uczelni studentów neuroróżnorodnych, spodziewana pracochłonność przygotowania zajęć dydaktycznych z ich udziałem. Ten stan może wzmacniać dyskurs wytworzony przez badania radykalizujące autyzm, w których występuje koncentracja na trudnościach, problemach, deficytach studentów neuronienormatywnych, które należy rekompensować (Cai i Richdale, 2016; Cullen, 2015; Moore-Gumora, 2014; Stefańska-Klar, 2010; NIK, 2020; Lindyberg i Woynarowska, 2016; Szmania, 2016; Opatowicz, 2021). Oczywiście nie można podważyć wartości tych badań. Wykonano mnóstwo dobrej roboty, wszak na jej podstawie uruchomiono 
wiele mechanizmów wsparcia kompensacyjno-terapeutycznego definiowanego jako systemowy, specjalistyczny system pomocowy obejmujący wszystkie sfery akademickiego życia studentów. Na uczelniach zorganizowano pomoc psychologiczną, konsultacje psychiatryczne, wdrożono programy adaptacyjne, wprowadzono szkolenia dotyczące komunikacji, szkolenia dla pracowników dydaktycznych i administracyjnych, programy trwałego wsparcia indywidualnego studentów, wprowadzono asystenta, wydrukowano ulotki informujące o tym, jak się zachować wobec osób niestabilnych emocjonalnie i neuroróżnorodnych w skrajnych sytuacjach (zob. uczelnianie strony Biur ds. Studentów Niepełnosprawnych). Jednak zwracam uwagę, że mamy tu dwie warstwy semantycznego przekazu, dwa równoległe dyskursy. Dyskurs rozumiem za R. de Beaugrande'em: każda kultura wytwarza określone znaczenia, w języku jest ich teoria, natomiast „dyskurs jest praktyką teorii” kreującą „system aktualnych wyborów” (2008, s. 107). W naszym przypadku mówi się i pisze o wspomaganiu w pokonywaniu przez studentów trudności oraz o reagowaniu/bronieniu się przed niespodziewanymi zachowaniami, podpowiadając procedury zachowań, o czym świadczą materiały instruktażowe zamieszczone na stronach uczelni. Mamy zatem przekaz o problematyczności wniesionej do uczelni wyższej przez studentów neuroróżnorodnych, co nie jest bez znaczenia dla naszej intersubiektywności (o medialnym dyskursie: Drzazga-Lech i Świątkiewicz-Mośny, 2018). Drugą niejasną kwestią jest mocny nacisk na wspomaganie, które w wiedzy potocznej może się kojarzyć z nauczycielem wspomagającym, towarzyszącym uczniowi w klasie szkolnej (na niższych szczeblach edukacji). Taki pedagog jest profesjonalnie przygotowany w zakresie pedagogiki specjalnej, ma kompetencje diagnostyczne oraz bardzo często terapeutyczne. Jego zadaniem jest wspomaganie ucznia o specjalnych potrzebach edukacyjnych oraz nauczyciela prowadzącego przedmiot. W uczelni wyższej natomiast funkcja ta została ulokowana w biurach do spraw osób niepełnosprawnych, w których profesjonaliści psychologowie i pedagodzy opracowują wytyczne przydatne w pracy dydaktycznej (na podstawie opisu diagnostycznego, jeżeli ujawni go student, oraz własnego wywiadu ze studentem). W tej sytuacji idea pomocności jest realizowana głównie przez zespół pracujący w uczelnianej jednostce dedykowanej studentom niepełnosprawnym, a zatem jest obok procesu dydaktycznego, ma wspomagać nauczyciela i jego pracę dydaktyczną oraz studenta (zob. Banach i Krzanowska, 2017). Osobą decyzyjną jest student, który ma świadomość swoich potrzeb, trudności i sposobów uczenia się, a w ewentualnych kłopotach ma wokół siebie osoby gotowe go wspomóc. W ramach zajęć dydaktycznych głównie nastawiamy się na różnorodność, czyli otwieranie w jej granicach potencjału studiujących. W trakcie mogą się pojawić skutki zaburzeń czy choroby, które mogą spowodować jakieś odmienności w organizacji procesu dydaktycznego (np. obniżenie aktywności studenta, potrzebę czasowej indywidualizacji procesu, wycofanie z pracy zespołowej) W takich sytuacjach z pedagogicznej perspektywy nie chodzi również o wspieranie, ale nadal o tworzenie warunków sprzyjających otwieraniu potencjału młodych ludzi. 


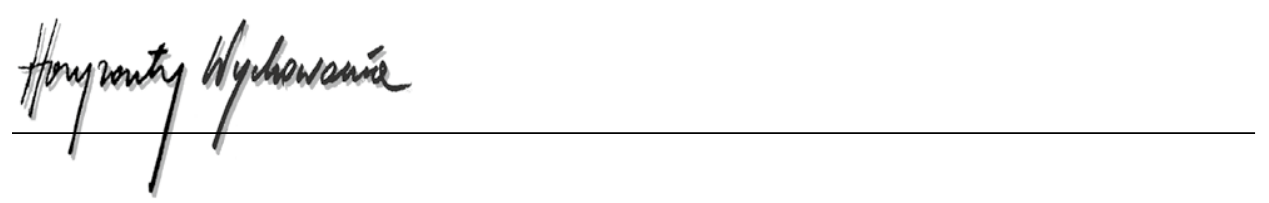

\section{Konkluzje z badań}

Nietypowym, a jednak bardzo przekonującym podsumowaniem tego artykułu niech będą słowa znanej na całym świecie samorzeczniczki osoby z autyzmem, uczonej, profesorki nauk biologicznych Temple Grandin:

Obecnie jestem profesorem w State University, ale w latach sześćdziesiątych byłam znudzoną szkołą średnią uczennicą, która rzadko się uczyła. Byłam ciągle spięta, dokuczano mi (...), ale moim zbawieniem był pan Carlock, mój nauczyciel przedmiotów ścisłych. Zaprojektował zajęcia i w swoim laboratorium naukowym zapewnił schronienie $z$ dala od presji i codzienności życia społecznego nastolatków. Przyjaźnie powstały poprzez wspólne zainteresowanie się elektroniką, modelami rakiet, końmi i jeździectwem. Uczniowie, którzy byli zainteresowani tymi specjalistycznymi działaniami, nie dokuczali mi. Do tego czasu nie potrafiłam się uczyć, ponieważ w szkole średniej nie miałam celu. Dopiero projekty Carlocka zainteresowały mnie nauką. Celem dla mnie stało się zostanie naukowcem, co dało mi motywację do nauki. (...) Na spotkaniach w trakcie rozmów z rodzicami, nauczycielami i specjalistami w odniesieniu do wysokofunkcjonujących uczniów z autyzmem i zespołem Aspergera wychodzą fakty potwierdzające, że udane kariery tych osób zaczęły się od nauczycieli, którzy motywowali ich do odniesienia sukcesu (Grandin, 2006, s. 229).

Przywołane myśli definiują znaczenie kunsztu pedagogicznego, dobrej dydaktycznej pracy i roli, jaką mogą odegrać akademiccy nauczyciele w losach osób neuroróżnorodnych. W przywołanej wypowiedzi odczytuję kilka istotnych sensów pracy dydaktycznej w uczelni wyższej: merytoryczne zaangażowanie stało się kluczowe dla zaangażowania w naukę, rozwiązało problem odrzucenia rówieśniczego, stało się źródłem poczucia sukcesu oraz celów życiowych. Jednocześnie zwracam uwagę na wysoką samoświadomość Grandin, która łączy fakty, nadaje im znaczenia i interpretuje. W tej wypowiedzi jak w soczewce ujawnia się moc sprawcza edukacji oraz rola, jaką mamy do odegrania.

Wszyscy zarówno neurotypowi, jak i neuroodmienni mają do zaoferowania światu siebie z atutami i słabościami, z którymi musimy sobie radzić. Medyczne podejście uzasadnione w terapii, jednak w pedagogicznych przekonaniach czyniące z osób neuronienormatywnych jednostki deficytowe, „do poprawy”, napiętnowane niedostosowalnością, w swojej istocie wyraża słabość otoczenia społecznego, kultury i edukacji, która narzuca normy i egzekwuje je, miast elastycznie reagować. Zmiana paradygmatu ma polegać na połączeniu działań specjalistycznych medycznych, psychologicznych, w sferze organizacji życia na uczelni, po które zwraca się autonomicznie osoba dorosła i tu mowa jest o wsparciu kompensacyjno-terapeutycznym. Natomiast równolegle w działaniach edukacyjnych, w które zaangażowane są podmioty edukacji (nauczyciele, grupa studencka wraz osobami neuroróżnorodnymi), odbywa się otwieranie potencjału każdego studenta w trzech wymiarach. W pierwszym tworzenie warunków sprzyjających zrozumienie siebie i świata, w drugim identyfikowanie mocnych stron osoby, czyli jej potencjału, i w trzecim dostosowanie sytuacji dydaktycznych do osobniczych potrzeb, zainteresowań i możliwości, jakimi dysponuje dana osoba. 
Dotykamy wszechogarniających nas zmian społeczno-kulturowych, nowych zagrożeń życia i zdrowia (kataklizmy, pandemia), mierzymy się jako społeczeństwo z egotyzmem, emocjonalnością i niepewnością ontologiczną, deregulacją, indywidualizmem, depersonalizacją i wieloma innymi dolegliwościami (Marody, 2015, Cierzniewska i in., 2017). Młode pokolenie, nasi studenci są w podwójnym zapętleniu: zadań rozwojowych (konstytuowania własnej tożsamości - relacji do siebie i świata) oraz nieprzewidywalności świata, za który mają wziąć w przyszłości odpowiedzialność. Przeciążenia mentalne i emocjonalne pokolenia „płatków śniegu”, pięknych i nietrwałych/niewytrwałych ludzi z tak zwanego pokolenia Z, już dają o sobie znać „epidemią” depresji i samobójstw. Nie można tych faktów ignorować w edukacji akademickiej, one muszą wpłynąć na naszą dydaktyczną otwartość. Stąd moje podkreślenie, że każdy student powinien odnaleźć siebie, każdy ma taką potrzebę (tzw. neuronormatywny, neuroróżnorodny, sprawny, niepełnosprawny, zdrowy, chory) i jeżeli dysponuje warunkami intelektualnymi, to akademickie kształcenie może stworzyć szanse otwierające jego potencjał i zaangażowanie w życie.

Wszelkiego typu zmiany zaczynają się od naszych przekonań, w tym przypadku od wiedzy o fenomenie autyzmu, o osobach neuroróżnorodnych. Badania potwierdziły, że specyfika poznawcza predysponuje ich do kształcenia akademickiego, choć mogą się pojawić pewne zaburzenia rozwojowe, sytuacyjne lub chorobowe. Studiowanie może być dla nich szansą na wzmocnienie poczucia wartości i przygotowania się do życia dorosłego. Wysoka świadomość siebie, sposobów uczenia się oraz własnych potrzeb czyni ich partnerami w procesie dydaktycznym, który elastycznie konstruowany może przynieść bardzo dobre efekty. Słowa studenta opisującego swoje oczekiwania wobec nauczyciela będą „wizytówką” neuroróżnorodności.

(...) nie prosiłem ani nie szukałem dodatkowego wsparcia, ponieważ uważam, że jest ono w dużej mierze niepotrzebne. Większość rzeczy, które oferują takie usługi, prawdopodobnie niewiele pomaga w moim konkretnym przypadku. Nie chcę pomocy w nawiązywaniu przyjaźni, bogatego życia towarzyskiego, specjalnych zajęć dla osób niepełnosprawnych itp. Chcę być w stanie poradzić sobie z lękiem na tyle, aby funkcjonować zawodowo (...) i być samodzielnym, jak to tylko możliwe (Gurbuz i in., 2019, s. 622).

\section{BIBLIOGRAFIA}

Attwood, T. (2013). Zespół Aspergera. Kompletny przewodnik (A. Sawicka-Chrapkowicz, tłum.). Harmonia Universalis.

Bakker, T.C., Krabbendam, L., Bhulai, S. i Begeer, S. (2019). Background and enrollment characteristics of students with autism in higher education. Research in Autism Spectrum Disorders, 67, 101424. DOI:10.1016/j.rasd.2019.101424

Bakker, T.C., Krabbendam, L., Bhulai, S. i Begeer, S. (2020), First-year progression and retention of autistic students in higher education: A propensity score-weighted population Study. Autism in Adulthood, 2(4). DOI:10.1089/aut.2019.0053

Banach, M. i Krzanowska, M. (2017). Nauczanie języków obcych w kontekście pracy indywidualnej ze studentem z niepełnosprawnością (np. deficytami ruchowymi, psychicznymi) - dydaktyka nauczania oraz logistyka współpracy z Biurem ds. Osób Niepełnosprawnych. W: J. Małocha 


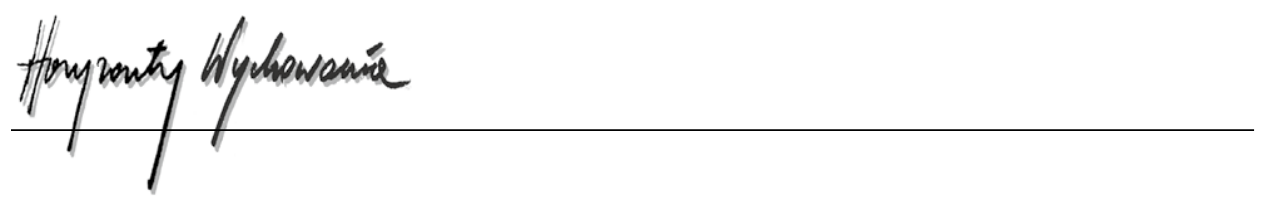

(red.), Interdyscyplinarny charakter badań językowych. Od dydaktyki do kulturoznawstwa (s. 1137). Uniwersytet Papieski Jana Pawła II. http://dx.doi.org/10.15633/9788374386081.02

Baron-Cohen, S. (2021). Poszukiwacze wzorców. Autyzm a ludzka wynalazczość (A. Nowak-Młynikowska, tłum.). Wydawnictwo Smak Słowa.

Beaugrande, R. de (2008). Krytyczna analiza dyskursu a znaczenie „demokracji” w wielkim korpusie (J. Kozak, tłum.). W: A. Duszak i N. Fairclough (red.), Krytyczna analiza dyskursu. Interdyscyplinarne podejście do komunikacji społecznej (s. 103-120). Towarzystwo Autorów i Wydawców Prac Naukowych „Universitas”.

Berger, P. i Luckman, T. (2010). Społeczne tworzenie rzeczywistości (J. Niżnik, tłum.). Wydawnictwo Naukowe PWN.

Bogdashina, O. (2019). Trudności w percepcji sensorycznej w autyzmie i zespole Aspergera. Inne doświadczenia sensoryczne - inne światy percepcyjne (A. Sawicka-Chrapkowicz, tłum.). Harmonia Universalis.

Brzezińska, A., Kaczan, R. i Rycielska, L. (2010). Przekonania o swoim życiu. Spostrzeganie historii życia przez osoby z ograniczeniami sprawności. Wydawnictwo Naukowe Scholar. https://www. researchgate.net/publication/281377455

Cai, R.Y. i Richdale, A. (2016). Educational experiences and needs of higher education students with autism spectrum disorder. Journal of Autism and Developmental Disorders, 46, 31-41. https://doi.org/10.1007/s10803-015-2535-1

Charlton, B. i Rosenkranz, P. (2016). Evolution of empathizing and systemizing: Empathizing as an aspect of social intelligence, systemizing as an evolutionarily later consequence of economic specialization. The Winnower, 8:e146194.40165. DOI:10.15200/winn.146194.40165

Cierzniewska, R., Gackowska, M. i Lewicka, M. (2017). Młodzież o sobie i codzienności szkolnej. Obok dyskursu jakości. Wydawnictwo Adam Marszałek.

Cisłak, K., Henne, K. i Skarżyńska, K. (red.). (2009). Przekonania w życiu jednostek, grup, społeczności. Wydawnictwo Szkoły Wyższej Psychologii Społecznej „Academica”.

Cullen, J.A. (2015). The needs of college students with autism spectrum disorders and Asperger's syndrome. Journal of Postsecondary Education and Disability, 28(1), 89-101. https://eric. ed.gov/?id=EJ1066322

Dijkhuis, R.L., de Sonneville, L., Zirmans, T., Staal, W. i Swaab, H. (2020). Autism symptoms, executive functioning and academic progress in higher education students. Journal of Autism and Developmental Disorders, 50(4), 1353-1363. doi:10.1007/s10803-019-04267-8

Drzazga-Lech, M. i Świątkiewicz-Mośny, M. (2018). Analysis of media representations of non-neurotypical students in the context of suport for people with autism spectrum disorders offered by Polish State owned universities - sociological study. Studia Humanistyczne AGH, 17(3), 31-48. http://dx.doi.org/10.7494/human.2018.17.3.31

Frith, U. (2005). Asperger and his syndrome. W: U. Frith (red.), Autism and Asperger's syndrome (s. 1-36). Cambridge University Press. https://doi.org/10.1017/CBO9780511526770.001

Gelbar, N.W., Smith, I. i Reichow, B. (2014). Systematic review of articles describing experience and supports of individuals with autism enrolled in college and university programs. Journal of Autism and Developmental Disorders, 44(10), 2593-2601. DOI:10.1007/s10803-014-2135-5

Grandin, T. (2006). Perspectives on education from a person on the autism spectrum. Educational Horizons, 84(4), s. 229-234. https://files.eric.ed.gov/fulltext/EJ750625.pdf

Grandin, T. i Panek, R. (2021). Mózg autystyczny. Podróż w głąb niezwykłych umysłów (K. Mazurek, tłum.). Copernicus Center Press.

Gurbuz, E., Hanley, M. i Riby, D.M. (2019). University students with autism: The social and academic experiences of university in the UK. Journal of Autism and Developmental Disorders, 49, s. 617-631. https://doi.org/10.1007/s10803-018-3741-4 
Hendrickx, S. (2018), Kobiety i dziewczyny ze spektrum autyzmu (M. Moskal, tłum.). Wydawnictwo Uniwersytetu Jagiellońskiego.

Huang, A.X. i Wheeler, J.J. (2006). High-functional autism: an overview of charakteristics end related issues, International Journal of Special Education, 21(2), 109-123. https://files.eric.ed.gov/ fulltext/EJ843611.pdf

Hull, L., Petrides, K.V. i Mandy, W. (2020). The female autism phenotype and camouflaging: a narrative review. Review Journal of Autism and Developmental Disorders, 7, 306-317. https://doi. org/10.1007/s40489-020-00197-9

Kim, C. (2018). Nieśmiali, skryci i społecznie niedopasowani. Przewodnik po życiu z zespołem Aspergera (J. Gilewicz, tłum.). Wydawnictwo Uniwersytetu Jagiellońskiego.

Klus-Stańska, D. (2018). Paradygmaty dydaktyki. Myśleć teorią o praktyce. Wydawnictwo Naukowe PWN.

Krahn, T.M. i Fenton, A. (2012). The extreme male brain theory of autism and the potential adverse effects for boys and girls with autism. Journal of Bioethical Inquiry, 9, 93-103. https://doi. org/10.1007/s11673-011-9350-y

Lindyberg, I. i Woynarowska, A. (2016). Wsparcie dorosłości osób z Autystycznego Spektrum Zaburzeń w Polsce. Rozwiązania systemowe, możliwości i ograniczenia. Niepełnosprawność. Dyskursy Pedagogiki Specjalnej, 24, 80-95.

Marody, M. (2015). Jednostka (po)nowoczesności. Perspektywa socjologiczna. Wydawnictwo Naukowe Scholar.

Molloy, H. i Vasil, L. (2002). The social construction of Asperger syndrome: the pathologising off diference? Disability \& Society, 17(6), 659-669. https://doi.org/10.1080/0968759022000010434

Moore-Gumora, C. (2014). A study of students on the autism spectrum transformation in a high school transition program. Educational Leadership and Administration: Teaching and Program Development, 25, 77-91. https://files.eric.ed.gov/fulltext/EJ1028954.pdf

NIK. (2020). Wsparcie osób z autyzmem i zespołem Aspergera w przygotowaniu do samodzielnego funkcjonowania. https://www.nik.gov.pl/plik/id,22196,vp,24863.pdf

Opatowicz, D. (2021). Bariery w edukacji osób z autyzmem. W: A. Karpińska, W. Wróblewska i P. Remża (red.), Edukacja zorientowana na ucznia i studenta (s. 255-269). Wydawnictwo Uniwersytetu w Białymstoku.

Pisula, E. (2018), Autyzm. Przyczyny, symptomy, terapia. Wydawnictwo Harmonia.

Płatos, M. (red.). (2016). Ogólnopolski spis autyzmu. Sytuacja młodzieży i dorosłych z autyzmem w Polsce. Stowarzyszenie Innowacji Społecznych „Mary i Max”. http://www.spisautyzmu.pl/ index_files/raport_OSA.pdf

Podgórska-Jachnik, D. (2021). Raport merytoryczny. Edukacja włączająca-bilans otwarcia 2020. Ośrodek Rozwoju Edukacji. https://www.ore.edu.pl/wp-content/plugins/download-attachments/ includes/download.php?id=33886

Prizant, B.M. i Fields-Meyer, T. (2017). Niezwyczajni ludzie. Nowe spojrzenie na autyzm (J. Bilmin-Odrowąż, tłum.). Wydawnictwo Uniwersytetu Jagiellońskiego.

Ricoeur, P. (1985). Egzystencja i hermeneutyka. Rozprawa o metodzie (E. Bieńkowska, tłum.). Pax. Rybakowski, F., Białek, A., Chojnicka, I., Dziechciarz, P., Horvath, A., Janas-Kozik, M., Jeziorek, A., Pisula, E., Piwowarczyk, A., Słopień, A., Sykut-Cegielska, J., Szajewska, H., Szczałuba, K., Szymańska, K., Urbanek, K., Waligórska, A., Wojciechowska, A., Wroniszewski, M. i Dunajska, A. (2014). Zaburzenia ze spektrum autyzmu - epidemiologia, objawy, współzachorowalność i rozpoznawanie. Psychiatria Polska, 48(4), 653-665.

Rynkiewicz, A. Janas-Kozik, M. i Słopień, A. (2019). Dziewczęta i kobiety z autyzmem. Psychiatria Polska, 53(4), 737-752.

Rynkiewicz, A., Łucka, I. i Fryze M. (2012). Wyskokofunkcjonujące dziewczęta z autyzmem i zespołem Aspergera - przyczyny rzadkiego diagnozowania i opis przypadków. Psychatria, 9(2), 43-52. 


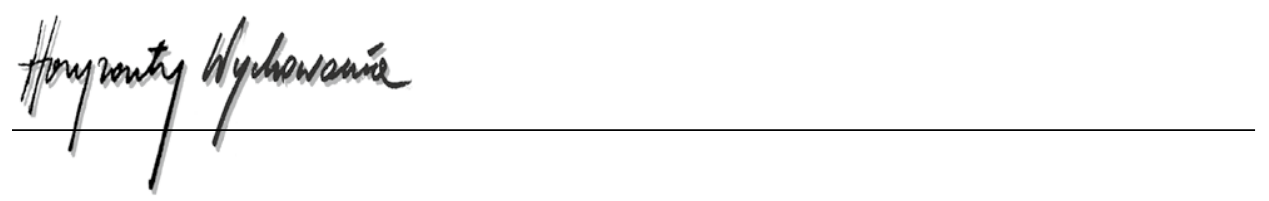

Sajdak, A. (2013). Paradygmaty kształcenia studentów i wspierania rozwoju nauczycieli akademickich. Teoretyczne podstawy dydaktyki akademickiej. Oficyna Wydawnicza Impuls.

Schütz, A. (2008). O wielości światów. Szkice z socjologii fenomenologicznej (B. Jabłońska, tłum.). Zakład Wydawniczy NOMOS.

Simone, R. (2016). Aspergergirls. Siła kobiet z zespołem Aspergera (J. Okuniewski, tłum.). Harmonia Universalis.

Schütz, A. (2008). O wielości światów. Szkice z socjologii fenomenologicznej (B. Jabłońska, tłum.). Zakład Wydawniczy NOMOS.

Simone, R. (2016). Aspergergirls. Siła kobiet z zespołem Aspergera (J. Okuniewski, tłum.). Harmonia Universalis.

Sławińska, A. (2014). Zespół Aspergera u osób dorosłych - zbieżność z innymi zaburzeniami, zaburzenia współwystępujące i problemy towarzyszące. Psychiatria i Psychologia Kliniczna, 14(4), 304-307. DOI: 0.15557/PiPK.2014.0041

Stefańska-Klar, R. (2010). Studenci z autyzmem i zespołem Aspergera. Funkcjonowanie, przyczyny sukcesów i porażek, warunki skutecznego wspierania. W: I. Bieńkowska (red.), W kręgu resocjalizacji $i$ wybranych zagadnień rozwoju oraz funkcjonowania osób niepełnosprawnych (t. 2, s. 91-107). Wydawnictwo Scriptum.

Szmania, L. (2016), Możliwości i ograniczenia osób z zaburzeniami spektrum autyzmu w realizacji własnych wizji dorosłości. Studia Edukacyjne, 39, 331-349.

Trusz, S. (2011). Rozwój poznawczo-społeczny dziecka w świetle oczekiwań interpersonalnych rodziców i nauczycieli. Psychologia Rozwojowa, 16(2), 21-32.

Wing, L.(2005). The relationship between Asperger's syndrome and Kanner's autism. W: U. Frith (red.), Autism and Asperger's syndrome (s. 93-121). Cambridge University Press. https://doi. org/10.1017/СBO9780511526770.003

\section{Copyright and License}

This article is published under the terms of the Creative Commons Attribution - NoDerivs (CC BY- ND 4.0) License http://creativecommons.org/licenses/by-nd/4.0/ 